九病虫研会報 $45 ： 38-44$ (1999)

Kyushu Pl. Prot. Res. 45 : 38-44 (1999)

\title{
長崎県の露地ビワに発生した果実腐敗の原因と 分離されたビワ扊斑病菌の薬剤感受性
}

\author{
古賀 敬一* \\ （長崎県果樹試験場）
}

\begin{abstract}
Outbreaks of fruit rot on loquat and occurrence of benomyl fungicide low sensitivity strains of Pestalotiopsis eriobotrifolia and Pestalotiopsis neglecta, the causal fungi of loquat gray leaf spot, in Nagasaki Prefecure. Keiichi KoGA (Nagasaki
\end{abstract} Fruit Tree Experiment Station, Omura, Nagasaki 856-0021)

key words: benomyl, fruit rot, loquat. Pestalotiopsis eriobotrifolia, Pestalotiopsis neglecta

\section{緒言}

長崎県の特産である露地ビワは，長崎半島に位置する 長崎市の南西部と三和町を主体に栽培されており，この 地域で本祡のビワ栽培面積の約80\%を占めているが, 1997年および1998年の 2 カ年連続して果実腐敗が多発し た(第 1 図)。また，果実の防腐郕として従来からべン ズイミダゾール系楽威が使用されてきたが，近年，生産 現場からはその効果を疑問視する声があった。そこで， 腐敗の発生原因について調查するとともに, ベノミルに

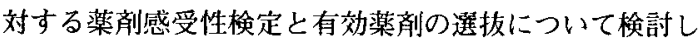
たのでその概要を報告する。

なお，本試験を進めるに当たって現地調查等に御協力 頂いた長崎県長崎農業改良普及センターおよびJ A 長崎, ならびにビワ灰斑病菌について御助言を賜った鹿児岛県 農業試験場病虫部の野岛秀伸氏に対して厚く御礼申し上 げる。

\section{材料および方法}

\section{1. 露地ビワ産地における腐敗果の発生原因調查}

1998年 5 月15日に J A 長崎管内の 4 力所から持ち込ま れた76果，5月22日に長崎市大崎地区，千々地区および 三和町川原地区を現地調查しそその3 力所から採取した 126果, 6 月 3 日に大村市の長崎県果樹試験場内で採取 した60果の合計262果について，腐敗部位を調査した。 そして、組織分離法 ${ }^{101}$ により腐敗果から菌を分離した後, $\mathrm{PDA}$ 培地上に置床し， $25^{\circ} \mathrm{C} て ゙ 10$ 日以上暗黒下で培養し

*現在 長崎県加津佐農業改良普及センター

*Present address: Nagasaki Kazusa Agricultural Extention Center, Kazusa, Nagasaki 859-2601
て分生子粘塊を形成させた。この分生子を光学顕微鏡下 で観察し，分生子の形態によって菌の種類を同定した。

2. ビワ灰斑病菌 (Pestalotiopsis eriobotrifolia, Pestalotiopsis neglecta）の種の同定と分離比率の 調查

腐敗果および䍜病葉から組織分離法16引によりビワ灰斑 病菌であるPestalotiopsis 属菌を分離し, 上述の方法で分 生子粘塊を形成させた。この分生子を光学顕微鏡下で観 察し，野島ら ${ }^{[3]}$ の報告に従って分生子の形態の違いをも とにP. eriobotrifolia または P. neglecta と同定した。さら に採取場所ごとにこれら 2 種の分雕比率を調查した。供 試菌株は, 長崎市の茂木地区, 大崎地区, 千々地区, 宮 摺地区，三和町川原地区朽よび大村市の長崎県果樹試験 場内から採取した47果から 1 菌株ずつ分離した計 47 菌秼, 罹病葉 1 葉あたり 1 病斑から 1 菌株ずつ分離した計 156 菌株であった。

\section{3. ベノミルに対するビワ灰斑病菌の薬剤感受性挨定}

腐敗果から分離した47菌株および羅病葉から分離した 156菌株を PDA 培地に置床し， $25^{\circ} \mathrm{C} て ゙ 3$ 日間培養後に 伸長した菌丵の先端部を径 4 m 抜き, ベノミルの有効成分濃度が $1 ， 10,100$, $1,000 \mathrm{ppm}$ になるように調整した PDA 培地上に菌踣面

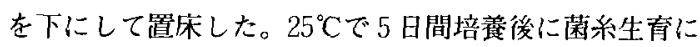
対するべノミルの最小生育阻止濃度 (MIC, minimum inhibitory concentration）を調查した。なお，薬剮感受 性菌の判定はチ十輪玟病菌（P. theae, P. longiseta) のベ ンズイミダゾール系薬郕に対する薬郕感受性検定の判定 基準に従い，MIC 値 $1 \mathrm{ppm}$ で生有しない菌株を感受性 菌, MIC 值 $1 \mathrm{ppm}$ で生育し $100 \mathrm{ppm}$ で生育しない菌株 を中等度の低感受性菌，MIC 值 100ppm を越えて生有 

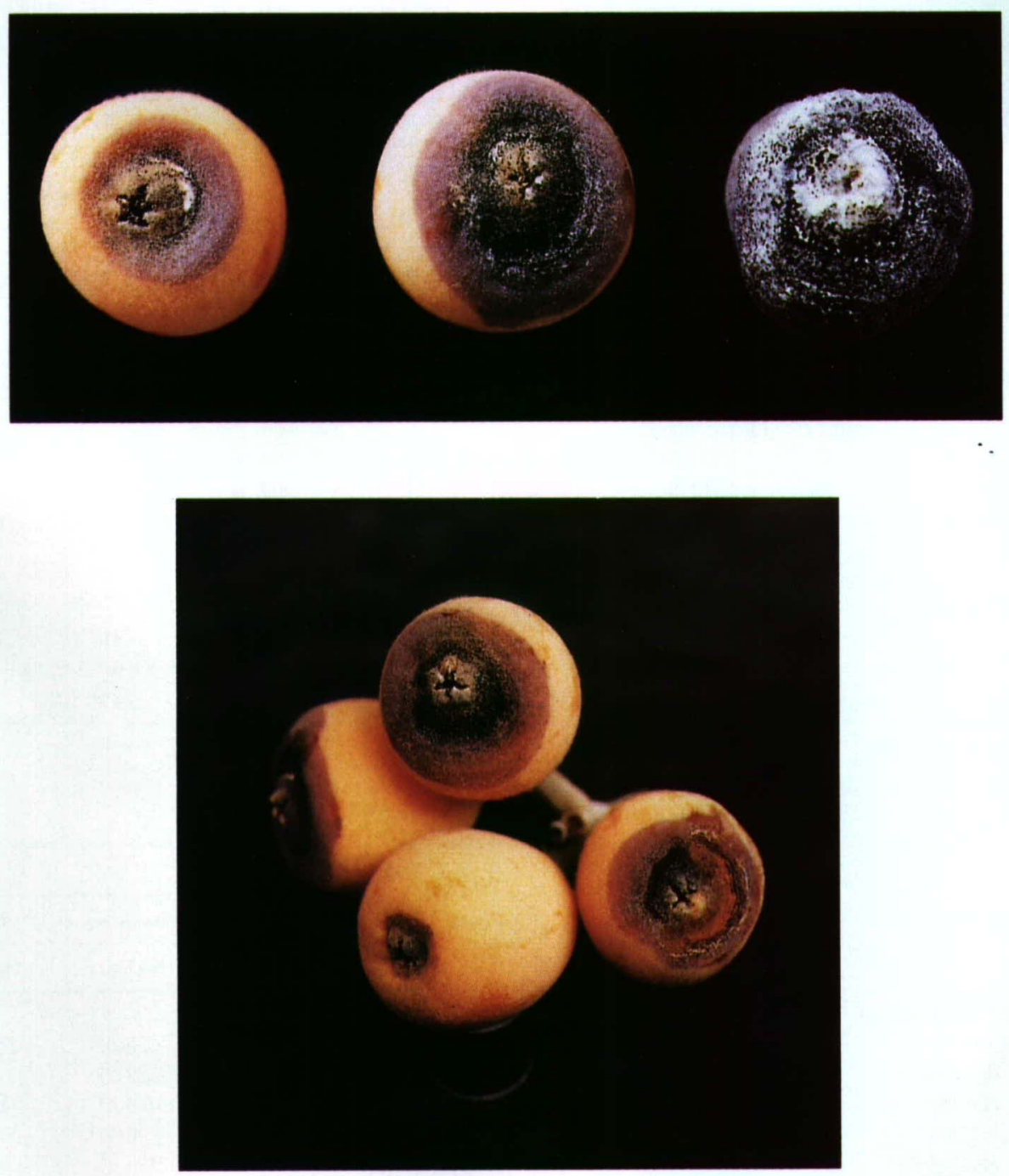

第1図ビワ灰斑病菌による果実腐敗

上段 : 左から右へ腐敗が進展する

下段：Pestalotiopsis 属菌単独（上下左側の果実）または C. acutatum との混合感染による 腐敗 (右側の果実)

する菌株を低感受性菌とした ${ }^{11)}$ 。

\section{4. ベノミル低感受性菌に効果のある薬剤の選抜}

ベノミル低感受性の P. eriobotrifolia 20菌株を用いて, 各菌株の菌叢先端部を径 $4 \mathrm{~mm}$ のコルクボーラーで打ち抜 き, 各種薬㶡の有効成分濃度が $1,5,10,50,100$, $500 ， 1,000 ， 5,000 \mathrm{ppm}$ になるように調整した PDA 培 地上に置床した。 $25^{\circ} \mathrm{C} て ゙ 5$ 日間培養後に菌叢直径（ディ スク直径の $4 \mathrm{~mm}$ を差し引いたもの) を測定して菌糸生育 量を求め, 併せて菌糸生有に対する各種薬剤の最小生育 阻止濃度（MIC）を調査した。供試薬剤は, ピワに対し て農薬登録のあるイミノクタジンアルベシル酸塩水和剤,
無機銅水和剤（ドライフロアプル），イプロジオン水和 剤, 今後登録予定のフルアジナム水和剤 $(\mathrm{SC})$, マンゼ ブ水和剤の 5 種類である。

$$
\text { 結果 }
$$

\section{1. 露地ビワ産地における果実の腐敗部位}

$\mathrm{J} \mathrm{A}$ 長崎からの持ち込みや現地および果樹試験場内か ら採取した262果のうち138果が果頂部から腐敗しており, 全体の $52.7 \%$ 占めていた。また, 果実内部のがく孔部 や維管束部が腐敗しているものや, 裂果や日焼けした跡 およびハマキムシ類等の食害跡から二次的に菌が感染し 
第 1 表 長崎暴内の露地ビワ産地における果実の腐敗部位（品種：茂木種）

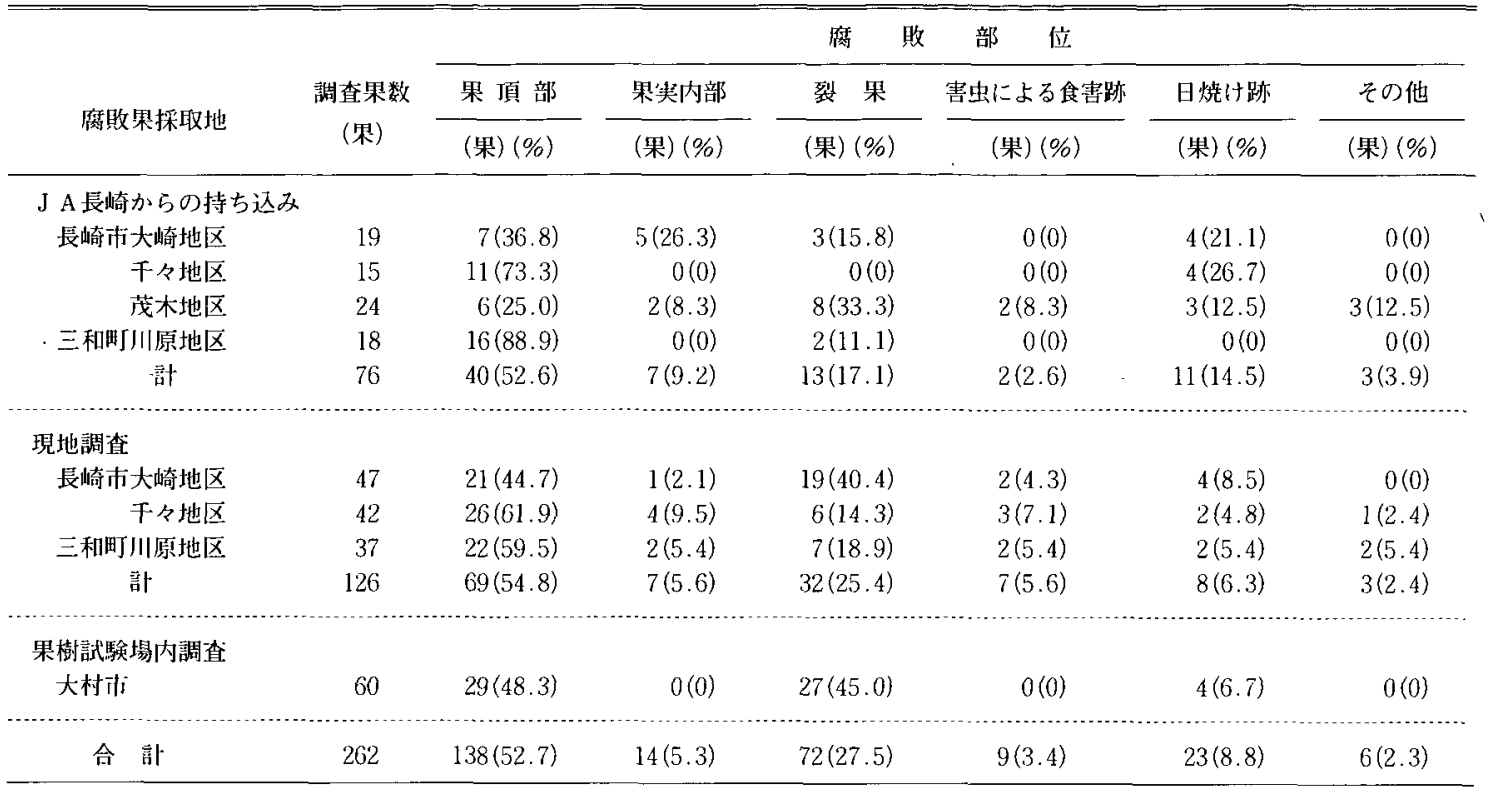

第乙表 ビワ應敗果から分離された系状菌の種類（品種：茂木㮔）

\begin{tabular}{|c|c|c|c|c|c|c|}
\hline \multirow{3}{*}{ 腐敗果採取地 } & \multirow{3}{*}{$\begin{array}{c}\text { 分離菌株数 } \\
\text { (株) }\end{array}$} & \multicolumn{5}{|c|}{ 分離された系状菌の種類 } \\
\hline & & Pestalotupsiss sp. & C. gloeosporioides & C. acutalum & Allernaria sp. & その他 \\
\hline & & (株) (\%) & (株) $(\%)$ & (株) (\%) & (株) (\%) & (株) $(\%)$ \\
\hline \multicolumn{7}{|c|}{$\mathrm{J} A$ 長崎からの持ち込巫 } \\
\hline 長崎市大崎地区 & 5 & $3(60.0)$ & $0(0)$ & $0(0)$ & $0(0)$ & $2(40.0)$ \\
\hline 千々地区 & 9 & $4(44.4)$ & $0(0)$ & $3(33.3)$ & $2(22.2)$ & $0(0)$ \\
\hline 茂林地区 & 15 & $3(20.0)$ & $1(6.7)$ & $0(0)$ & $10(66.6)$ & $1(6.7)$ \\
\hline 三和町川原地区 & 17 & $13(76.5)$ & $0(0)$ & $4(23.5)$ & $0(0)$ & $0(0)$ \\
\hline 計 & 46 & $23(50.0)$ & $1(2.2)$ & $7(15.2)$ & $12(26.1)$ & $3(6.5)$ \\
\hline \multicolumn{7}{|l|}{ 現地調植 } \\
\hline 長崎㭉大崎地区 & 35 & $13(37.1)$ & $3(8.6)$ & $15(42.9)$ & $2(5.7)$ & $2(5.7)$ \\
\hline 千々地区 & 46 & $30(65.2)$ & $0(0)$ & $15(32.6)$ & $1(2.2)$ & $0(0)$ \\
\hline 三利町川原地区 & 54 & $16(29.6)$ & $7(13.0)$ & $26(48.1)$ & $5(9.3)$ & $0(0)$ \\
\hline 計 & 135 & $59(43.7)$ & $10(7.4)$ & $56(41.5)$ & $8(5.9)$ & $2(1.5)$ \\
\hline \multicolumn{7}{|l|}{ 果樹試験場人調査 } \\
\hline 大村杖 & 26 & $9(34.6)$ & $8(30.8)$ & $6(23.1)$ & $0(0)$ & $3(11.5)$ \\
\hline 合 計 & 207 & $91(44.0)$ & $19(9.2)$ & $69(33.3)$ & $20(9.7)$ & $8(3.9)$ \\
\hline
\end{tabular}

て腐敗しているものもみられた（第 1 表）。

\section{2.ビワ腐敗果から分碏された糸状菌}

供試した207果のうち91果からはビワ㶮斑病菌である Pestalotiopsis 屏菌が分離され，全体の44.0\%を占めてい た。次いで，多犯性の炭瘨病菌である Colletotrichum acttatum が69果 $(33.3 \%)$ から分離さ机たが，ビり檪瘨病
菌であるC. gloeosporioides は19果（9.2\%）と少なかった。 その他に Alternaria 属菌も認められた(第2 表)。

3. ビワ灰斑病菌 (Pestalotiopsis eriobotrifolia, Pestalotiopsis neglecta) の種の同定と分離状況

果夷から分離された47菌株のうちP. eriobotrifolia が32 菌株 $(68.1 \%) ， P$. neglecta が15菌株 (31.9\%) であり， 
罹病葉から分離された156菌株ではP. eriobotrifolia が 86 菌株 $(55.1 \%), P$. neglecta が70菌株 $(44.9 \%)$ と, $P$. eriobotrifolia の分離率がまさっていた。しかし，果実打 よび罹病葉を採取した場所によってP. eriobolrifolia とP. neglectaの分離比率がそれぞれ異なっていた（第 3 表）。

\section{4. ベノミルに対するビワ灰斑病菌の薬㓮感受性}

果実から分離された 47 菌株のうち MIC 值 $1 \mathrm{ppm}$ 以下 の感受性菌が18菌株，MIC 值 $100 \mathrm{ppm}$ 以下の中等度の 低感受性菌が 2 菌株, MIC 值 $100 \mathrm{ppm}$ を越える低感受性 菌が 27菌株 $(57.4 \%)$ であった。一方，罹病葉から分

第 3 表 2 種のビワ在斑病菌 P. eriobotrifolia およびP. neglecla の分離状況

\begin{tabular}{|c|c|c|c|c|}
\hline \multirow{2}{*}{ 分離部位 } & \multirow{2}{*}{ 調査試料採取地 } & \multirow{2}{*}{$\begin{array}{l}\text { 調査菌 } \\
\text { 株 数 } \\
\text { (株) }\end{array}$} & \multirow{2}{*}{$\frac{\text { P. eriobotrifolia }}{\text { (株) }(\%)}$} & \multirow{2}{*}{$\frac{P . \text { neglecta }}{(\text { 株 })(\%)}$} \\
\hline & & & & \\
\hline \multicolumn{5}{|l|}{ 䏑敗果实 } \\
\hline & 長崎市茂木地区 & 2 & $2(100)$ & $0(0)$ \\
\hline & 大崎地区 & 6 & $4(66.7)$ & $2(33.3)$ \\
\hline & 千々地区(1) & 8 & $8(100)$ & $0(0)$ \\
\hline & 三和町川原地区(1) & 13 & $12(92.3)$ & $1(7.7)$ \\
\hline & 三和町川原地区(2) & 7 & $6(85.7)$ & $1(14.3)$ \\
\hline & 大村市 (果試) & 11 & $0(0)$ & $11(100)$ \\
\hline & 計 & 47 & $32(68.1)$ & $15(31.9)$ \\
\hline \multicolumn{5}{|l|}{ 罹病葉 } \\
\hline & 長崎市茂木地区 & 14 & $0(0)$ & $14(100)$ \\
\hline & 大崎地区 & 31 & $13(41.9)$ & $18(58.1)$ \\
\hline & 千々地区(1) & 34 & $29(85.3)$ & $5(14.7)$ \\
\hline & 千々地区(2) & 21 & $20(95.2)$ & $1(4.8)$ \\
\hline & 宮摺地区 & 27 & $8(29.6)$ & $19(70.4)$ \\
\hline & 三和町川原地区 & 23 & $16(70.0)$ & $7(30.0)$ \\
\hline & 大村市(果試) & 6 & $0(0)$ & $6(100)$ \\
\hline & 計 & 156 & $86(55.1)$ & $70(44.9)$ \\
\hline
\end{tabular}

第 4 表 長崎県内のビワ産地におけるビワ灭斑病菌のべノミルに対する感受性

\begin{tabular}{|c|c|c|c|c|c|c|c|c|}
\hline \multirow{3}{*}{ 分嚾部位 } & \multirow{3}{*}{$\begin{array}{c}\text { 猿查試料 } \\
\text { 採取地 }\end{array}$} & \multirow{3}{*}{$\begin{array}{c}\text { 調查菌株数 } \\
\text { (株) }\end{array}$} & \multicolumn{5}{|c|}{ 最小生育阻此濃度 (MIC 值) 別の菌株数 } & \multirow{3}{*}{$\begin{array}{c}\text { 低感受性菌率 } \\
(\%)\end{array}$} \\
\hline & & & \multirow{2}{*}{$\frac{\text { 感受性菌 }}{\left(\begin{array}{c}\text { 1ppm } \\
(\text { 株 })\end{array}\right.}$} & \multicolumn{2}{|c|}{ 中等度の低感受性菌 } & \multicolumn{2}{|c|}{ 低感受性菌 } & \\
\hline & & & & $\begin{array}{c}10 \mathrm{ppm} \\
\text { (株) }\end{array}$ & $\begin{array}{c}100 \mathrm{ppm} \\
(\text { 株) }\end{array}$ & $\begin{array}{c}1.000 \mathrm{ppm} \\
(\text { 株 })\end{array}$ & $\underset{\text { (株) }}{1.000 \mathrm{pm}}$ 以上 & \\
\hline \multicolumn{9}{|l|}{ 腐敗果実 } \\
\hline & 長崎市茂木地区 & 2 & 1 & 1 & 0 & 0 & 0 & 0 \\
\hline & 大崎地区 & 6 & 0 & 0 & 1 & 1 & 4 & 83.3 \\
\hline & 千々地区 & 8 & 2 & 0 & 0 & 0 & 6 & 75.0 \\
\hline & 三和町川原地区(1) & 13 & 0 & 0 & 0 & 0 & 13 & 100.0 \\
\hline & 三和町川原地区(2) & 7 & 5 & 0 & 0 & 0 & 2 & 28.6 \\
\hline & 大村市（果試） & 11 & 10 & 0 & 0 & 0 & 1 & 9.1 \\
\hline & 計 & 47 & 18 & 1 & 1 & 1 & 26 & 57.4 \\
\hline \multicolumn{9}{|l|}{ 䍜病葉 } \\
\hline & 長崎市茂木地区 & 14 & 12 & 1 & 0 & 0 & 1 & 7.1 \\
\hline & 大崎地区 & 31 & 8 & 0 & 7 & 0 & 16 & 51.6 \\
\hline & 千々地区(1) & 34 & 27 & 0 & 0 & 0 & 7 & 20.6 \\
\hline & 千々地区(2) & 21 & 1 & 0 & 6 & 2 & 12 & 66.7 \\
\hline & 宮摺地区 & 27 & 18 & 0 & 7 & 0 & 2 & 7.4 \\
\hline & 三和町川原地区 & 23 & 19 & 1 & 0 & 1 & 2 & 13.0 \\
\hline & 大村市 (果試) & 6 & 4 & 0 & 0 & 0 & 2 & 33.3 \\
\hline & 計 & 156 & 89 & 2 & 20 & 3 & 42 & 28.8 \\
\hline
\end{tabular}


第 5 表 2 種のビワ灰斑病菌のベノミルに対する感受性検定

\begin{tabular}{|c|c|c|c|c|c|c|c|c|}
\hline \multirow{3}{*}{$\begin{array}{l}\text { ビ ワ } \\
\text { 灰斑病菌 }\end{array}$} & \multirow{3}{*}{ 分㢕部位 } & \multirow{3}{*}{$\begin{array}{c}\text { 調查菌 } \\
\text { 株 数 } \\
\text { (株) }\end{array}$} & \multicolumn{5}{|c|}{ 最小生育阻止濃度（MIC 值）と阻止された菌株数 } & \multirow{3}{*}{$\begin{array}{c}\text { 低感受性菌率 } \\
(\%)\end{array}$} \\
\hline & & & \multirow{2}{*}{$\frac{\text { 感受性菌 }}{\begin{array}{c}\text { 1ppm } \\
(\text { 株) }\end{array}}$} & \multicolumn{2}{|c|}{ 中等度の低感受性菌 } & \multicolumn{2}{|c|}{ 低 感受 性 菌 } & \\
\hline & & & & $\begin{array}{c}10 \mathrm{ppm} \\
(\text { 株) }\end{array}$ & $\begin{array}{c}100 \mathrm{ppm} \\
(\text { 株 })\end{array}$ & $\begin{array}{c}1.000 \mathrm{ppm} \\
(\text { 株 })\end{array}$ & $\begin{array}{c}1,000 \mathrm{ppm} \text { 以上 } \\
\text { (株) }\end{array}$ & \\
\hline \multirow[t]{3}{*}{ P. eriobotrifolia } & 腐敗果実 & 32 & 8 & 1 & 0 & 0 & 23 & 71.9 \\
\hline & 籊病葉 & 76 & 42 & 0 & 5 & 2 & 27 & 38.2 \\
\hline & 計 & 108 & 50 & 1 & 5 & 2 & 50 & 48.1 \\
\hline \multirow[t]{3}{*}{ P. neglecta } & 腐敗果実 & 15 & 10 & 0 & .1 & 1 & 3 & 26.7 \\
\hline & 罹病葉 & 62 & 31 & 1 & 15 & 0 & 15 & 24.2 \\
\hline & 計 & 77 & 41 & 1 & 16 & 1 & 18 & 24.7 \\
\hline
\end{tabular}

離された156菌株については感受性菌が89菌株，中等度 の低感受性菌が22菌株，低感受性菌が45菌株 (28.8\%) であった。果実抢よび櫂病葉の採取場所によって調查し た菌株数が異なるが，いずれも長崎市大崎地区，千々地 区，三和町川原地区で低感受性菌が多く認められた（第 4 表)。また，P. eriobotrifolia およびP. neglecta とも低感 受性菌の存在が確談され，調查した全菌株のうち $P$. eriobotrifolia の $48.1 \%, P$. neglecta $の 24.7 \%$ が低感受性菌 であった（第 5 表)。

\section{5.ベノミル低感受性菌に効果のある薬㓮の選抜}

ベノミル低感受性であるP. eriobotrifolia の菌糸生育を 最も抑制したのはイミノクタジンアルベシル酸塩水和剤 で，1ppm でも菌系生有が抑制され，50ppm 以上では菌 系はほとんど伸長しなかった。フルアジナム水和浏 （SC）は $5 \mathrm{ppm}$ から菌系生育が抑制されたが，100ppm までは若干の菌系生育がみられた。しかし，菌系生育の 進展はイミノクタジンアルベシル酸塩水和剤以外の薬郕 に比べて極端に遅かった。また，イプロジオン水和剤で も菌系生有の抑制がみられたが，その効果はイミノクタ

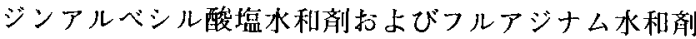
（SC）より低かった（第２図）。また，菌系生有の最小 生有阻蹧度（MIC）は，イミノクタジンアルベシル酸 塩水和戍の効果が最も高く, MIC 値のピークは $10 \mathrm{ppm}$ であった。次いでフルアジナム水和剛 (SC) で MIC 值のピークは $500 \mathrm{ppm}$ であった(第3図)。

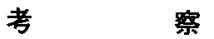

長崎県における露地ビワの㢁敗果から最も多く分離さ れた糸状菌はビワ灰斑病菌であるPestalotiopsis 属菌で,

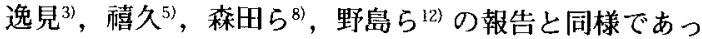
た。また，森田 ${ }^{9}$ は長崎県におけるビワ病害の発生につ いて調查したところ，1980年時点でビワ扊斑病の発生直 場率は62.7\%と高く，発病葉率も1980年に27.7\%であっ

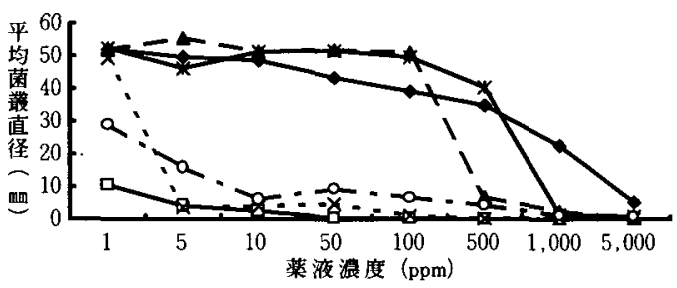

第2 図 ベノミル低感受性ビワ灰斑病菌（P. eriobolrifolin） に対する各種薬骩の菌叢生育抑制効果
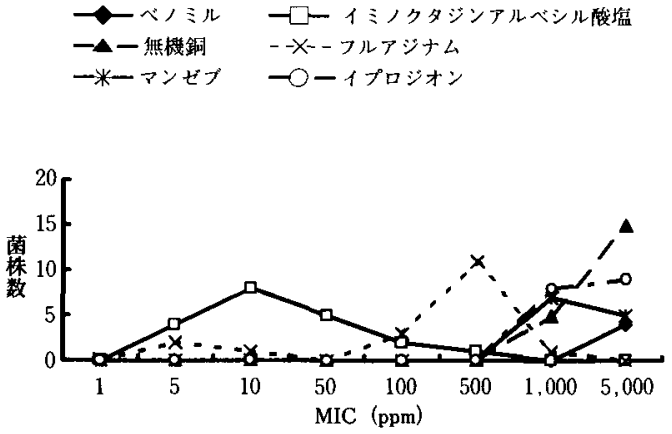

第 3 图各種薬骫に対するベノミル低感受性ビワ灰斑病菌 (P. eriobolrifolia) の感受性頻度分布

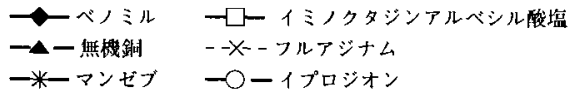

たものか゚1989年に72.7\%と増加傾向にあることを報告し ている。すなわち，本県のビワ産地はビワ扊斑病罹病樹 の割合が高いために，葉に形成された病斑から多量の分 生子が飛散しており，園内における病原菌密度は以前に 比べて上昇しているものと思われる。本病の分生子の我 散時期について，禧久ら ${ }^{6}$ は 6 月上旬一 7 月中旬が最も 多く，飛散が終息するのは10月中旬頃であると報告して いる。しかし，春葉および夏葉の病斑上に胞子が形成さ れるのは10月上旬以降で，11月下旬にかけて急速に増加 するとしており ${ }^{4)}$ 野島ら ${ }^{14}$ はビワからの Pestalotiopsis 属菌の分離頻度は，出蕾期から収穕期にかけて高まる傾 
向にあることを示している。また，果実腐敗の発生は収 穫前の降雨量との相関が高いとされているが8.9)，この 場合, 根部から水分を過剩に吸収して生じる裂果跡から 二次的に菌が感染して腐敗することは考元られるものの， すでに果実は袋掛けされている状態なので，果頂部に直 接感染することは困難である。これらのことから，ビワ の開花初期にあたる10月中旬以降に感染したものが果頂 部のがく孔内部に潜伏し, 果実が成熟するにつれて潜伏 感染していた菌が腐敗を引き起こすものと考えられ、こ のことが果頂部からの腐敗が多かった原因ではないかと 推察される。Pestalotiopsis 属菌に次いで多く分離された のはビワ炭疽病菌である Colletotrichum 属菌であったが, 從来型の C. gloeosporioides ${ }^{10)}$ より，イチゴや他の作物等 寄主範囲が広く多犯性で, ベンズイミダゾール系薬骩に 耐性である C. acutatum ${ }^{17-199}$ が優占していることが判明 した。

ベンズイミダゾール系薬㘊は, ビワ灰斑病菌や炭瘟病 菌による腐敗果の防除のみならず，これら病原菌の春葉 および夏葉への感染を防止する薬凬として使用されてき た。今回実施したべノミルに対する薬剤感受性検定の結 果から, MIC 值 $1 \mathrm{ppm}$ 以下の感受性菌の他にすべての 調查地点で MIC 值 $100 \mathrm{ppm}$ を越える低感受性菌が存在 しており，特にビワ主産地である長崎市大崎地区，千々 地区，三和町川原地区で低感受性菌率が高かった。また， これらの低感受性菌の大部分はべノミル $1,000 \mathrm{ppm}$ 含有 PDA 培地上でも生有した。これらの産地ではビワ栽培 の歴史が長く, ベンズイミダゾール系薬㘊の使用頻度が 高いために低感受性菌が出現したものと思われる。この 低感受性菌の存在がベノミルによる防腐効果の低減に関 与している可能性が高く，耐性菌の疑いが強いが，この 点については, 今後ビワに対する接種試験を行いベンズ イミダゾール系薬冎効力低下の再現を確認した上で判 断したい。

ビワ灰斑病菌はP. funerea ${ }^{10)}$ とされているが，野島 $ら^{133}$ によると分生子の形態が原や小西》が報告したもの

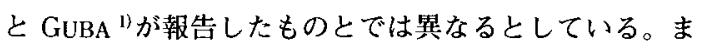
た, 病原性が確認された 2 種のビワ灰斑病菌が小西》の 報告と形態的に対応することから、ビワ灰斑病の病原菌 として P. eriobotrifolia およびP. neglecta を提案している。 今回の試験で長崎県内のビワから分離された P. eriobotrifolia およびP. neglectaは，いずれもべノミルに対する低 感受性菌が存在することが判明した。さらにこれら低感 受性菌を用いてベンズイミダゾール系薬骩の代替剤を検 討した結果, 坂口ら ${ }^{15)}$ が報告したイプロジオン水和剤や マンネブ・チオファネートメチル水和㖁よりイミノクタ
シシンアルベシル酸壏水和䨩の方が菌系生育抑制効果が高 く, MIC 值のピークも $10 \mathrm{ppm}$ と低濃度であった。

ビワ灰斑病に対する今後の対策は, 羅病葉の除去等伝 染源の密度低下を図るとともに，果実だけでなく春葉お よび夏葉への本病原菌の感染防止のため, イミノクタシ ンアルベシル酸塩水和骫を組み込んだ楽剤防除体系の確 立が必要である。また，ビワに登録のある薬剮の中で C. acutatum に効果の高い薬郕がないので，有効薬郕の選 报と農薬登録の促進を図る必要がある。

以前からビワ果実腐敗の発生生悲については数多くの 報告があり，市場病害のひとつとして重要視されてき

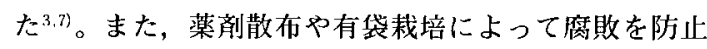
する手段が見出されているにもかかわらず未だに腐敗が 多発するということは，防除法や薬骩感受性低下の問題 だけでなく，果実からみた病原菌に対する感受性の変化 や各品種の特性, 出荷から店頭に並ぶまでの輸送や貯蔵 技術の向上など幅広い研究が必要であると思われる。

\section{摘 要}

1. 露地ビワの果实腐敗は, 果頂部から腐敗している ものが多く，大部分がビワ兏斑病菌 (P. eriobotrifolia お よびP. neglecta) であった。

2. ビワ灰斑病菌であるP. eriobolrifolia と P. neglecta の分離比率は，果実および羅病葉ともP. eriobotrifolia が まさったが，採取した場所によって P. eriobotrifolia と $P$. neglectaの優占種が異なっていた。

3.ビワ灰斑病菌のベノミルに対する薬澈感受性検定 を行った結果, MIC 值 $1 \mathrm{ppm}$ 以下の感受性菌と MIC 值 $100 \mathrm{ppm}$ 以下の中等度の低感受性菌および MIC 值が $100 \mathrm{ppm}$ を越える低感受性菌の3 群に分かれた。低感受 性菌率は果実からの分離菌株で57.5\%, 羅病葉からの分 離菌株では $28.8 \%$ でった。これら低感受性菌は露地ビ ワの主産地である長崎市大崎地区，千々地区，三和町川 原地区で多く認められた。また，P. eriobotrifolia および P. neglecta ともにべノミルに対する低感受性菌の存在が 確認された。

4. ベノミル低感受性のP. eriobotrifolia に対して低濃 度で菌系生有を抑制した薬敦はイミノクタジンアルベシ 几酸塩水和凬で, MIC 值のピークは $10 \mathrm{ppm}$ であった。

\section{引 用 文 献}

1) GuBA, E.F. (1961) Harvard Univ. Press : pp. 154 . 2) 原 掑祐(1916) 果樹病害論：pp.455. 3) 逸見武雄 (1930) 農 及園 10:297-317.4) 秸久 保・坂口徳光 (1984) 九病虫研 会報 $30: 68-70.5)$ 融久 保 (1985) 九病虫研会報 31 : 74-76. 6) 禧久 保. 坂口德光 (1987) 九病虫研会報 33 ： 
88-90，7）小酉全太郎 (1937) 植物病害研究 $3: 137-146$. 8）菻田 昭. 永野道昭 (1986) 九農研 $48 ： 157$ ，9）森田 炤 (1990) 九病虫研会報 $36 ： 76-80 ， 10 ＼mathrm{~ 日 本 植 物 病 理 学 会 編 ~}$ （1984）日本有用植物病名目録 3 日植防協会：pp .88-90. 11)

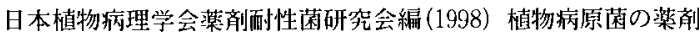

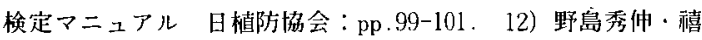
久保·熊本 修(1995) 九病虫研会報 $41: 36-42$, 13) 野岛 秀伸・小林亭夫 ·青木孝之・和泉勝一. 坂口德光 (1996) 日植病 報 $62: 26$ (講要)。14) 野岛秀伸・和泉勝一(1996) 日植病

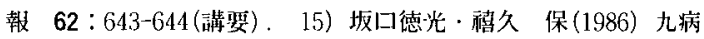

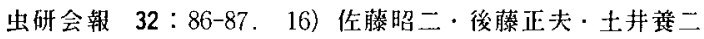
(1983) 植物病理学実験法請談社サイエンテ1

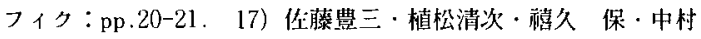
靖弘(1994）日植病報 $60: 339-340$ (講要)。18) 佐藤䅧三. 植 松清次 ·溝口一美・禧久 保. 三浦猛夫 (1997) 日植病報 63 ： 16-20. 19) 仵藤豊三(1997) 四国㥀防研 $32: 1-19$.

(1999年 4 月30日 受領) 